\title{
The impact of ethics and fraud pentagon theory on academic fraud behavior
}

\author{
${ }^{1)}$ Dhita Permata Wira Utami
}

dp.wirautami@gmail.com

${ }^{2)}$ Dian Indri Purnamasari

dian_indri@upnyk.ac.id

${ }^{1,2)}$ Fakultas Ekonomi dan Bisnis, Universitas Pembangunan Nasional “Veteran” Yogyakarta

\begin{abstract}
This study aims to determine the impact of ethics, pressure, opportunity, rationalization, competence, and arrogance on accounting students' academic fraud behavior. The population of this research consists of UPN "Veteran" Yogyakarta accounting students. The number of samples used in this study was 170 respondents representing several criteria and have taken the Auditing I and Business Ethics courses. The dependent variable $(Y)$ in this study is academic fraud behavior. The independent variables include ethics $\left(X_{1}\right)$, pressure $\left(X_{2}\right)$, opportunity $\left(X_{3}\right)$, rationalization $\left(X_{4}\right)$, competence $\left(X_{5}\right)$, and arrogance $\left(X_{6}\right)$. The method used in this research is the quantitative method. The data used were the primary data. The results of this study indicate that ethics, pressure, and competence have an impact on academic fraud behavior. In contrast, opportunities, rationalization, and arrogance do not affect academic fraud behavior.
\end{abstract}

Keywords: Ethics; Fraud; Cheating Behavior.

\section{Introduction}

Accounting education aims to prepare students to become professional accountants and to meet the anticipated future need for professional accounting services. For that reason, accountants lacking in professionalism will not sell quite well in the job market. Accounting focuses on reporting financial information. However, in recent times, professional managers and accountants have acknowledged the importance of additional economic information that neither accounting nor financial reporting systems can produce. It is believed that the information is not always concerning financial matters. Still, it gives deeper meaning to the reported data to provide more in-depth information for the decisionmaking processes. Some of these non-financial information belongs to the area of behavioral accounting. Behavioral accounting is a branch of accounting that integrates behavioral dimension into traditional accounting (Handayani, 2018).

Dishonesty seems to be quite prevalent today. Almost every day, various mass media provide news about fraudulent practices that are deeply entrenched and increasingly difficult to overcome in our country. Numerous corruption scandals reported in the press are perpetrated by various professional groups, including an accountant. Fraud committed by accountants must be taken seriously by policymakers in education, especially accounting education. Accountants' involvement in various recent financial scandals or 
those that occurred over the past decade has exposed accountant integrity to public scrutiny. The latest data from the Association of Certified Fraud Examiners (2014) stated that the accounting department constitutes the largest part of the professional world's fraud perpetrator. Therefore it is necessary for accounting education to provide a constructive response to this and to improve the moral competence of prospective accountants (Artani \& Wetra, 2017).

As the agents of change, the next generation and future accountants, students shall avoid those fraudulent practices for the betterment of their future profession. Inculcating ethical behavior and moral values and developing social relationships will certainly not be enough when it is limited to education in the classroom. Creating a favorable environment for ethical behaviors will provide a more decisive impetus for students to get used to being honest and to asserting an opinion of dishonesty that may occur anywhere. That way, universities' role in preparing for high-quality graduates can be performed well.

The reason for choosing the University of National Development "Veteran" Yogyakarta (subsequently abbreviated to UPNVY) as the object of study, especially students of the accounting department of Economics and Business Faculty, is that the university has been nicknamed 'the Campus of National Defense.' The UPNVY got the nickname because the university is run under the auspices of the Department of Defense. The concept of national defense is also manifested in the education curriculum of UPNVY. It has a vision for becoming a pioneer in national development in the spirit of national security in this era of globalization.

\section{Theoretical Framework and Hypothesis Development}

\subsection{Ethics and Fraud}

The word ethics, derived from the late Latin ethica, also means moral philosophy. It is a guideline for how to behave appropriately from a cultural, moral, and religious perspective. Alternatively, Keraf argued that ethics is literally derived from Greek Ethos (plural: ta etha), which means precisely similar to morality: to have good habits. In general, ethics is defined as behavioral values or rules accepted and practiced by a particular group or individuals. Ethics talks about the moral values and norms that determine human behavior in his life (Suraida, 2005).

In his Fraud-Examination, Albrecht stated that fraud is a generic term and embraces all the multifarious means which human ingenuity can devise, which are resorted to by one individual to get an advantage over another by false representations. No definite and invariable rule can be laid down as a general proposition in defining fraud, as it includes surprise, trickery, cunning, and unfair ways by which another is cheated. The only boundaries defining it are those which limit human knavery.

Donald R. Cressey developed the fraud triangle theory in 1953. This is the first theory that explains the elements that cause fraud, and there have been many studies that confirmed the fraud triangle. Cressey conducted extensive research with convicted 
criminals to determine what motivates seemingly honest people to commit fraud. The three components of the fraud triangle are pressure, opportunity, and rationalization.

In 2004, Wolfe \& Hermanson (2004) refined the fraud triangle theory to fraud diamond theory, which consists of pressure, opportunity, rationalization, and competence. There is an additional element in the latter fraud theory, i.e., competency. Competency is defined as individual capability, and it plays a crucial role in the fraud. Successful fraudulent practices depend on one's ability, which consists of position, intelligence, egocentrism, persuasiveness, deceit, and stress control (Wolfe \& Hermanson, 2004).

Fraud pentagon theory is developed by Marks (2012) from previous Crowe's Fraud Pentagon Theory. According to Crowe, arrogance is identified with a sense of superiority and a feeling of entitlement. Arrogance is greed as part of a person who believes that internal control does not apply to them. Fraud perpetrators believe that the implemented internal controls cannot befall them, so they usually think freely without fear of sanctions that will trap them.

\subsection{Hypothesis Formulation}

Forsyth described ethics as the primary goal of professional behavior, which is closely related to the prevailing morals and values based on idealism and relativism. In a Litbang Media Group survey, predominant academic fraud at high school and university level is cheating. By academic fraud, we mean behaviors deliberately perpetrated by high school students, such as violating the rules for assignments or exams or helping their classmates in dishonest completion of tasks or exams (Pudjiastuti, 2012).

Albrecht describe pressure is when someone feels the need to commit academic fraud (Puspitasari et al., 2019). The pressure is defined as a strong urge that exists within students' feeling from his self or environment to achieve specific goals that arise owing to too many demands or tasks that must be done (Nurkhin \& Fachrurrozie, 2018). A study by McCabe et al. (2001) indicates that one of the factors related to students' pressure is when they have many activities outside the campus. Students involved in many off-campus activities are more prone and closer to academic cheating behavior (Murdiansyah et al., 2017). Apriani et al. (2017) argues that pressure affects fraud behaviors among accounting students. Puspitasari et al. (2019) show that anxiety has a significant impact on academic fraud behavior among accounting students across the universities in Malang.

The more excellent the opportunity, the higher the possibility for the occurrence of fraud behavior will be. Opportunity is a factor that encourages academic fraud to occur. The more significant opportunity a person has to commit fraud, the higher possibility that they will do so. A person can be motivated to commit fraud by a perceived opportunity, such as a chance for gaining benefits from other sources. Option means either available or sought out opportunities in a classroom situation that entices a university student to commit fraud behaviors under loose exam supervision or to jointly commit academic dishonesty together with his or her classmate (Nurkhin \& Fachrurrozie, 2018). All these confirm the findings of Apriani et al. (2017), stating that the opportunity impacts students' academic fraud behavior. Puspitasari et al. (2019) show that option has a significant impact 
on academic fraud behavior among accounting department students across the universities in Malang. Fitri (2019), in contrast, shows that opportunity has no effect on fraudulent procurement of goods or services in the Local Government of Aceh.

Rationalization is a self-justification or a wrong excuse for wrong behavior (Albrecht, 2003). McCabe et al. (1997) state that rationalization is a behavior that shows students' habits to regard cheating as an act consistent with their code of ethics in their environment (Murdiansyah et al., 2017). Rationalization is a strong reason student have to justify their academic fraud acts (Nurkhin \& Fachrurrozie, 2018). This conforms to the findings of Apriani et al. (2017), stating that rationalization has an impact on students' academic fraud behaviors. Puspitasari et al. (2019) show that rationalization significantly impacts academic fraud behavior among accounting students across universities in Malang. In contrast, Fitri (2019) demonstrates that rationalization does not affect the fraudulent procurement of goods or service in the Aceh government.

Competency here is the ability of a person to commit fraud acts. Thus, competence is a person's ability to override internal control, develop sophisticated concealment strategies, and control social situations for his benefit by selling them to others (Marks, 2012). More specifically, the competency here is students' ability to override internal control, develop concealment strategies, and control social situations for their benefit (Nurkhin \& Fachrurrozie, 2018). The results of a study by Fitrianti (2019) demonstrate that competency impacts academic fraud. Murdiansyah et al. (2017) show that competency has a significant impact on reducing academic fraud behaviors. Puspitasari et al. (2019), conversely, demonstrates that competency is rejected or has no effect.

Arrogance is a person's attitude revealing that internal controls, company policies, and regulations do not apply to him. He feels that he is exempt from procedures, regulations, and internal control. Therefore he 'innocently' commits fraud (Nisa \& Oktafiana, 2019). Achsin \& Cahyaningtyas (2019) also suggest that arrogance can arise when a person has a sense of superiority or can commit fraud without being foiled by any control. Therefore, he did so without fear of sanctions that will trap him. Faradiza (2019) reveals that arrogance has no impact on fraudulent financial reporting. The study results by Febriana (2019) indicate that students' arrogance does not encourage them to commit academic fraud in competency assessment. Based on the above conceptual framework, we propose the following hypotheses:

$H_{1}:$ Ethics have an impact on academic fraud behavior

$\mathrm{H}_{2}$ : Pressure has an impact on academic fraud behavior

$H_{3}$ : Opportunity has an impact on academic fraud behavior

H4: Rationalization has an impact on academic fraud behavior

H5: Competency has an impact on academic fraud behavior

H6: Arrogance has an impact on academic fraud behavior

\section{Methods}

The population consists of all accounting students of UPN Veteran of Yogyakarta. We use primary data collected directly from main sources through interviews upon which 
the answers to the research questions are based (Sugiyono, 2014). The samples were selected using a purposive sampling technique based on predetermined criteria, i.e., students who were currently taking or have taken Business Ethics and Auditing 1 courses. All questionnaires use 4 points Likert-scale questions that start with 1 (strongly disagree) to 4 (strongly agree).

Table 1. Research Instrument

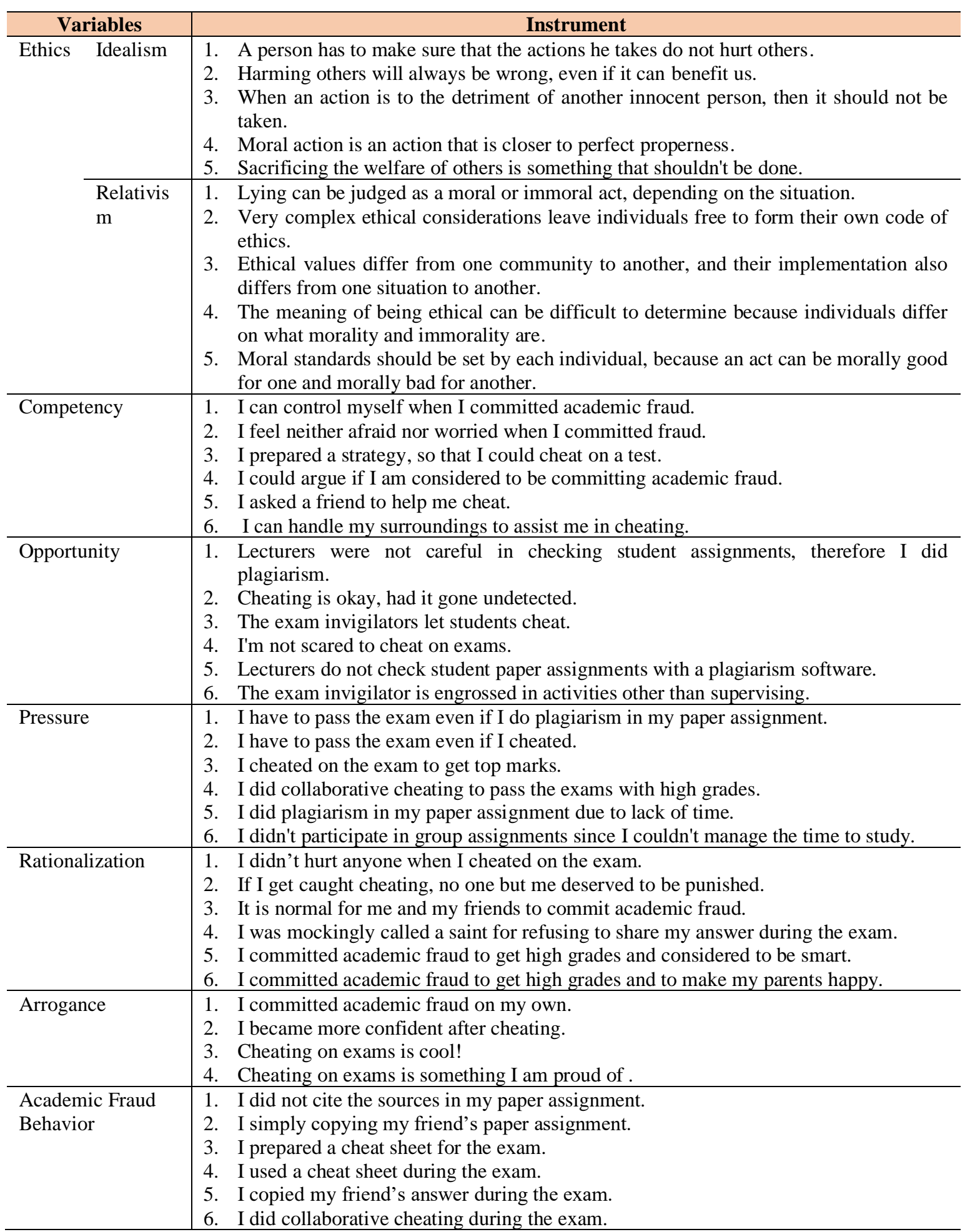




\section{Results and Discussion}

Respondents in this study consist of accounting students of the economics and business faculty in University of National Development "Veteran" Yogyakarta. The data collected are 170 questionnaires returned and eligible for analysis.

\subsection{Validity and Reliability Testing}

A validity test is conducted to measure the validity of the questionnaire. Questions on a questionnaire valid when they measure what they are supposed to measure (Ghozali, 2016). The validity test is conducted by counting the correlation between each question item's scores using Pearson's Product Moment. When a correlation indicates a p-value of less than 0.05 , this means significant. Therefore, the test is valid.

Reliability refers to the overall consistency of measure in assessing a questionnaire, which is an indicator of the variable. A questionnaire is reliable when one's answers to the questions are consistent and stable over time (Ghozali, 2016). The reliability test is conducted using Cronbach's Alpha Coefficient. A Cronbach's alpha of 0.6 indicates an acceptable level of reliability.

\subsection{Multiple Linear Regression Analysis}

Multiple linear regression analysis is used to explain the relationship between one dependent variable and the factors affecting more than one independent variable.

Table 2. Results of Multiple Linear Regression Analysis

\begin{tabular}{lcccl}
\hline \multicolumn{1}{c}{ Variable } & B & t & P value & \multicolumn{1}{c}{ Result } \\
\hline Ethics & -0.146 & -2.895 & $0.004^{*}$ & $\mathrm{H}_{1}$ : Accepted \\
Pressure & -0.345 & 4.067 & $0.000^{* *}$ & $\mathrm{H}_{2}$ : Accepted \\
Opportunity & 0.087 & 1.315 & 0.190 & $\mathrm{H}_{3}$ : Rejected \\
Rationalization & -0.037 & 0.410 & 0.692 & $\mathrm{H}_{4}$ : Rejected \\
Competence & 0.181 & 2.848 & $0.005^{*}$ & $\mathrm{H}_{5}$ : Accepted \\
Arrogance & 0.148 & 1.292 & 0.198 & $\mathrm{H}_{6}$ : Rejected \\
\hline F Value: 25.047 & & & $0,000^{* *}$ & \\
Adj R Square: 0.461 & & & & \\
* Sig <5\%, ** Sig $<1 \%$ & & & &
\end{tabular}

A constant value of 7.218 indicates that the constant value in equation is 7.218, which means that if the independent variables-ethics, pressure, opportunity, rationalization, competence, and arrogance — did not change or constant, then the academic fraud behavior would be 7.218. The regression coefficient of ethics ( $\left.b_{1}\right)$ is -0.146 , which means that if the ethics had 1 unit increase, the academic fraud behaviour would decrease by 0.146 , assuming that all other variables remain constant. The regression coefficient of pressure $\left(b_{2}\right)$ is 0.345 , which means that if the pressure had 1 unit increase, the academic fraud behavior would increase by 0.345 , assuming that all other variables remain constant. The regression coefficient of competence (bs) is 0.181 , which means that if the competence had 1 unit increase, academic fraud behavior would increase by 1.81, assuming that all other variables remain constant. 
The results stated that ethics has an impact on academic fraud behavior. This result indicates that the committed act is not harming others. That moral action is an action that is closer to perfect properness. That was sacrificing the welfare of others is something that shouldn't be done. That lying can be judged as a moral or immoral act, depending on the situation. That ethical values differ from one community to another, and their implementation also varies from one problem to another. Each individual should set moral standards because an act can be morally right for one and ethically bad for another, and affects academic fraud behavior. Forsyth describes ethics as the main objectives of professionalism closely related to applying moral rules and values based on idealism and relativism (Pudjiastuti, 2012). Idealism is an ethical value that refers to the individual belief that positive consequences happen due to a morally acceptable act. The point is that the desired results (positive outcomes) occurred when no one was harmed. Relativism, on the other hand, rejects moral judgment in any absolute sense. Individuals will take their local values, culture, or beliefs into consideration. One of the relativism aspects stated that ethical values originate not from one absolute perspective because individuals have their respective ethical behaviors. The results of $\mathrm{H} 1$ indicated that ethics have an impact on students' academic fraud behavior.

The results of the study revealed that pressure has an impact on academic fraud behavior. The pressure is the factor with the most significant effect on academic fraud behavior. This can be seen from its lowest significance level among other variables. Furthermore, based on the Standardized Coefficient, pressure has Beta $=0.440$, which is the most considerable $\mathrm{B}$ value. This result indicates that the forces of having to do well in exams, getting higher grades, having no sufficient time to complete the assignment, and failing to work on group assignments because of inability to manage the time impact academic fraud behavior. According to Tuanakotta (2010), pressure motivates an individual to commit fraud for financial or non-financial factors. The pressure is when a person feels the need to achieve academic fraud (Albrecht, 2003). The test of hypothesis 2 indicates that anxiety has an impact on students' academic fraud. McCabe et al. (2001) suggest that one factor related to the students' pressure is their involvement in many offcampus activities. Students with many off-campus activities are more prone or closer to academic fraud behavior (Murdiansyah et al., 2017). Apriani (2017) indicates that pressure affects fraud behavior among accounting students.

The present study revealed that opportunity has no impact on academic fraud behavior. The reason for this is that an effective control system has been implemented on campus. Therefore students find it difficult to commit fraud. Lecturers have been carefully checking students' assignments to keep them from plagiarism. Exam invigilators won't let students cheat. According to Tuanakotta (2010), the opportunity is a condition where individuals cheat because loopholes let them cheat without being detected, and no sanction is ever imposed on them. Individuals usually commit fraud by utilizing their expertise and skills. The more significant opportunities an individual gets, the higher likelihood that he will cheat. The testing of the third hypothesis indicated that opportunity has no impact on students' academic fraud. Fitri (2019) suggests that a better internal control system will 
result in a higher likelihood of detecting fraud in a simpler and faster way. Furthermore, this will help reduce the opportunity for committing fraud.

The results revealed that rationalization has no impact on academic fraud behavior. This result indicates the feeling that no one was harmed when committing fraud. That "if I get caught cheating, no one but me deserved to be punished." That "it is normal for my friends and me to commit academic fraud." That "I was mockingly called a saint for refusing to share my answer during the exam." That committing academic fraud to get high grades and considered smart and making parents happy will not affect students to commit academic fraud. According to Tuanakotta (2010), rationalization is an individual consideration to justify his or her fraud acts before actually committing fraud behavior. The testing of the fourth hypothesis indicates that rationalization has no impact on students' academic fraud behavior. This is because many respondents expressed their disagreement with statements concerning rationalization. They argued that one's rationalization in committing fraud can not be measured because it is a conscious thought to justify his or her fraud act.

The results indicated that competence has an impact on academic fraud behavior. This shows that self-control, the feeling of not being afraid or worried, the ability to argue when caught cheating, getting a friend to help cheat on exams, and the ability to handle the surroundings impact academic fraud behavior. According to Marks (2012), competence is a person's ability to override internal control, develop sophisticated concealment strategies, and control social situations for their benefit by selling them to others. The testing of the fifth hypothesis indicated that competence has an impact on students' academic fraud. This means that the higher ability a student has in academic fraud, the higher competence he gets for doing so. This study's results are consistent with those of Faradiza (2019).

The results of the study revealed that arrogance has no impact on academic fraud behavior. This means that students can commit fraud, increase confidence after committing fraud, feel that cheating in an exam is cool, and being proud of committing academic fraud has no impact on academic fraud. Nisa et al. (2019) stated that arrogance arises when a person considered himself as not subject to internal control, policies, or rules of his or her company, and thus feels he is not guilty when committing fraud. Muhsin et al. (2018) and Faradiza (2019) found that arrogance has no impact on fraudulent acts in financial reporting. Febriana (2019) revealed that students' superiority did not lead them to commit academic fraud on their competency test.

\section{Conclusions, Limitations, and Recommendations}

The findings show that ethics, pressure and competence have significantly impact on academic fraud behavior, while opportunity, rationalization, and arrogance have no significant effect on academic fraud behavior.

Our work has some limitations, such as getting more respondents, because the questionnaires were distributed during the semester break. It was also not possible for us to contact the respondents in a face-to-face survey. Therefore, we use a social media platform as an alternative way of distributing questionnaires. We propose the following 
recommendations to the parties concerned: for education practitioners, this study provides valuable information considering the impact of ethics, pressure, opportunity, rationalization, competence, and arrogance on academic fraud behavior in devising better learning methods or rules to minimize academic fraud among students. We also suggest that future research use other independent variables than those included in this study, such as religiosity, intelligence, personality, and self-efficacy. Furthermore, we recommend that further research should be taken in the area of fraud pentagon concept because some studies cited in this research paper provide results that run contrary to the existing theory.

\section{References}

Achsin, R. I. C. H. (2019). Studi fenomenologi kecurangan mahasiswa dalam pelaporan pertanggungjawaban dana kegiatan mahasiswa: Sebuah realita dan pengakuan. Journal of Chemical Information and Modeling, 53(9), 1689-1699. https://doi.org/10.1017/CBO9781107415324.004

Apriani, N., Sujana, E., \& Sulindawati, I. G. E. (2017). Pengaruh pressure, opportunity, dan rationalization terhadap perilaku kecurnagan akademik (Studi empiris: mahasiswa Akuntansi Program S1 Universitas Pendidikan Ganesha). E-Journal S1 $A k, 7(1), 121-133$.

Aprilia, A. (2017). Analisis pengaruh fraud pentagon terhadap kecurangan laporan keuangan menggunakan beneish model pada perusahaan yang menerapkan Asean corporate governance scorecard. Jurnal ASET (Akuntansi Riset), 9(1), 101. https://doi.org/10.17509/jaset.v9i1.5259

Artani, K. T. B., \& Wetra, I. W. (2017). Academic self efficacy dan fraud diamond. Riset Akuntansi, 7(2), 123-132.

Fadersair, K., \& Subagyo, S. (2019). Perilaku kecurangan akademik mahasiswa akuntansi: dimensi fraud pentagon (Studi kasus pada mahasiswa Prodi Akuntansi Ukrida). Jurnal Akuntansi Bisnis, 12(2), 122-147. https://doi.org/10.30813/jab.v12i2.1774

Faradiza, S. A. (2019). Fraud pentagon dan kecurangan laporan keuangan. EkBis: Jurnal Ekonomi Dan Bisnis, 2(1), 1-22.

Febriana, N. R., \& Novianti, N. (2019). Analisis pengaruh dimensi fraud pentagon terhadap perilaku kecurangan akademik mahasiswa pada uji kompetensi. Jurnal Ilmiah Mahasiswa FEB, 8(1).

Fitri, F., \& Nadirsyah, N. (2019). Pengaruh tekanan (pressure), kesempatan (opportunity), rasionalisasi (rationalization), dan kapabilitas (capability) terhadap kecurangan pengadaan barang/jasa di Pemerintahan Aceh dengan pemoderasi budaya etis organisasi. Jurnal Ilmiah Mahasiswa Ekonomi Akuntansi, 5(1), 69-84. https://doi.org/10.24815/jimeka.v5i1.15437

Ghozali, I. (2016). Aplikasi Analisis Multivariate dengan Program IBM SPSS. Edisi Kedelapan. Semarang: Badan Penerbit Universitas Diponegoro.

Handayani, M. H. \& A. E. (2018). Pengaruh kecerdasan emosional terhadap tingkat pemahaman akuntansi pada mahasiswa akuntansi di Universitas Dr Soetomo. Jurnal Analisa Akuntansi dan Perpajakan, 2(2), 86-98.

Hendricks, B. (2004). Academic dishonesty: A study in the magnitude of and justifications for academic dishonesty among college undergraduate and graduate students. Jurnal of College Student Development, 212-260. https://doi.org/10.1007/s12033-010-9324$\mathrm{Z}$

Marks, J. (2012). The mind behind the fraudsters crime: Key behavioral and environmental elements. Crowe Horwath LLP, 62. Retrieved from 
http://www.fraudconference.com/uploadedFiles/Fraud_Conference/ Content/CourseMaterials/presentations/23rd/ppt/10C-Jonathan-Marks.pdf

McCabe, D. L., Trevino, L. K., \& Butterfield, K. D. (2001). Dishonesty in academic environments: The influence of peer reporting requirements. Journal of Higher Education, 72(1), 29-45. https://doi.org/10.2307/2649132

Meliana, M., \& Hartono, T. R. (2019). Fraud perbankan Indonesia: Studi eksplorasi. Prosiding Seminar Nasional Pakar, 2-52.

Mia, T. P., Eindye, T., \& Satria, Y. W. (2019). Pengaruh Fraud Triangle Sebagai Prediktor Kecurangan Pelaporan Keuangan. Jurnal Bisnis Dan Akuntansi, 21(1), 77-88. https://doi.org/10.34208/jba.v21i1.502

Muhsin, Kardoyo, \& Nurkhin. (2018). What determinants of academic fraud behavior? From fraud triangle to fraud pentagon perspective. KnE Social Sciences, 3(10), 154. https://doi.org/10.18502/kss.v3i10.3126

Murdiansyah, I., Sudarma, M., \& Nurkholis. (2017). Pengaruh dimensi fraud diamond terhadap perilaku kecurangan akademik. Jurnal Akuntansi Aktual, 4(2), 121-133.

Nisa, K., Oktafiana, N. F., \& Permata Sari, S. (2019). Fraudulent financial statement ditinjau dari model fraud Pentagon Horwath. Urecol, 164-177.

Nurkhin, A., \& Fachrurrozie. (2018). Analisis pengaruh dimensi fraud diamond terhadap. Pendidikan Akuntansi, 1(1), 1-12.

Padmavathy, R., Amudhavalli, A., Manikandan, M., Rajeswarapalanichamy, R., Iyakutti, K., \& Kushwaha, A. K. (2019). Electronic and optical properties of CsSnI3-yCly (y $=0,1,2,3)$ Perovskites: a DFT Study. Journal of Electronic Materials, 48(2), 12431251. https://doi.org/10.1007/s11664-018-06850-8

Pamungkas, I. D. (2016). Pengaruh orientasi etika dan komitmen profesional terhadap kecurangan akuntansi melalui rasionalisasi sebagai variabel moderating. Ekonomi Dan Bisnis, 18, 41-54.

Pudjiastuti, E. (2012). Hubungan "Self Efficacy" dengan perilaku mencontek mahasiswa psikologi. MIMBAR, Jurnal Sosial Dan Pembangunan, 28(1), 103. https://doi.org/10.29313/mimbar.v28i1.344

Puspitasari, E., Amin, Moh., \& Mawardi, M. C. (2019). Pengaruh kompetensi sarjana akuntansi, regulasi pemerintah dan etika profesi terhadap kemampuan sarjana akuntansi untuk bersaing dalam menghadapi era revolusi industri 4.0. E-Jra, 08(01), $1-13$.

Sugiyono. (2014). Statistika Untuk Penelitian Kuantitatif. Bandung: Alfabeta.

Suraida, I. (2005). Pengaruh etika, kompetensi, pengalaman audit dan risiko audit terhadap skeptisisme profesional auditor dan ketepatan pemberian opini akuntan publik. Sosiohumaniora, 7(3), 186-202.

Tuanakotta, Theodorus. M. 2010. Akuntansi Forensik dan Auditor Investigatif. Lembaga Penerbit Fakultas Ekonomi Universitas Indonesia (LPFE UI). Edisi ke 2: Jakarta

Wardana, I. G. J., Sulindawati, I. N. L. G. E., \& Sujana, I. E. (2017). Pengaruh motivasi belajar, integritas mahasiswa dan penyalahgunaan teknologi informasi terhadap perilaku kecurangan akademik (Studi kasus pada mahasiswa Jurusan Akuntansi Program S1 Universitas Pendidikan Ganesha). E-Jurnal S1 Ak, 8(2).

Wati, M., \& Sudibyo, B. (2016). Pengaruh pendidikan etika bisnis dan religiusitas terhadap persepsi etis mahasiswa akuntansi. Jurnal Economia, 12(2), 183. https://doi.org/10.21831/economia.v12i2.11775

Wolfe, D. T., \& Hermanson, D. R. (2004). The fraud diamond: Considering the Four Elements of Fraud: Certified Public Accountant. The CPA Journal, 74(12), 38-42. https://doi.org/DOI: 
Yudiana, A. P., \& Lastanti, H. S. (2016). Analisis pengaruh dimensi fraud diamond terhadap perilaku kecurangan akademik mahasiswa Fakultas Ekonomi. Seminar Nasional Dan Call Paper Fakultas Ekonomi UNIBA Surakarta, (September), 412422. 